Tugas I review

\title{
SOSIO ANTROPOLOGI
}

HUBUNGAN SOSIO ANTROPOLOGI BUDAYA, GIZI DAN KESEHATAN

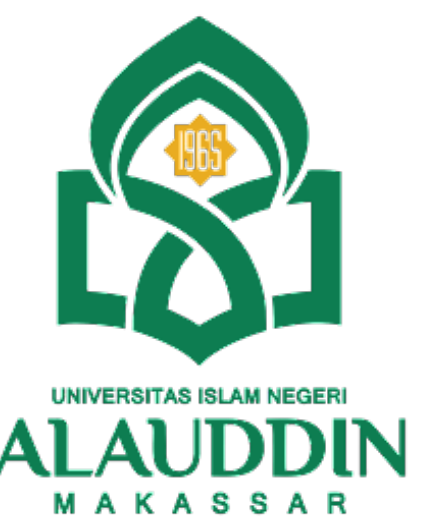

Disusun Oleh :

Nurul Bahjah Hasyim

bahjahasyim@gmail.com

70200121069

A ( semester 1)

PROGRAM STUDI KESEHATAN MASYARAKAT

FAKULTAS KEDOKTERAN DAN ILMU KESEHATAN

UNIVERSITAS ISLAM NEGERI ALAUDDIN MAKASSAR

2021 


\section{MENGATASI MASALAH BUDAYA DAN MAKANAN}

$\checkmark$ Perlunya kemampuan memanfaatkan masyarakat lokal sesuai dengan kearifan dan kecerdasan lokal : Melihat sumber daya alam dan potensi pangan daerahnya, perbaikan struktur sosial masyarakat terhadap pemahaman pangan, makanan dan gizi

$\checkmark$ Perbaikan gizi keluarga

$\checkmark$ Perbaikan budaya masyarakat pengaruh utama yaitu gender ( kesetaraan gender)

$\checkmark$ Sosialisasi terhadap gizi

\section{TUGAS :}

1. Pola dan sistem budaya terhadap makanan

Konsumsi makanan utama merupakan bagian paling besar dalam pola hidangan di Indonesia. Keadaan ini muncul karena adanya anggapan makanan utama merupakan makanan terpenting jika dibanding dengan jenis makanan lainnya. Suatu hidangan dianggap tidak akan sempurna jika tidak terdapat makanan pokok di dalamnya. Meskipun begitu, pandangan sosial budaya menganggap makanan mempunyai arti yang lebih luas daripada hanya sebagai sumber gizi. Hal ini terkait dengan adanya kepercayaan, posisi, prestis, pertemanan serta kedamaian dalam kehidupan manusia.

Pola makanan adalah suatu cara seseorang maupun kelompok memanfaatkan bahan makanan yang tersedia sebagai respon terhadap kondisi ekonomi serta sosialbudaya yang sedang terjadi. Makanan memiliki fungsi di dalam masyarakat secara sosial-politik. Hal ini meliputi kondisi lingkungan, kepercayaan, adat istiadat, kebiasaan, serta tingkat pendidikan masyarakat yang ditempuh. 


\section{Budaya.....}

Di Indonesia, keberagaman suku yang dimiliki menyebabkan adanya perbedaan dalam pemilihan makanan pokok. Bagi masyarakat Sunda dan Jawa, makanan pokok yang dikonsumsi adalah nasi. Sementara itu, masyarakat Madura mayoritas mengkonsumsi Jagung sebagai makanan pokoknya. Adanya perbedaan pemilihan makanan pokok ini menunjukkan adanya persepsi dan penilaian terhadap makanan sebagai sebuah budaya pokok di dalam suatu masyarakat. Hal ini dapat menjadi dasar mengapa bagi masyarakat Sunda, jika belum memakan nasi dianggap mereka belum makan meskipun mereka telah jenis makanan berat selain nasi.

Karena banyaknya rasa keraguan yang muncul akibat melimpahnya makanan olahan serta makanan cepat saji membuat banyak masyarakat kota berpindah untuk menjadi seorang vegetarian yang bertentangan dengan tradisi pangan di Indonesia. Kasus ini merupakan contoh bahwa makanan dapat menciptakan persepsi budaya tandingan terhadap budaya dominan yang berlaku di Indonesia.

Makanan pun dapat menjadi bagian dari budaya populer. Contoh makanan yang menjadi bagian dari budaya populer di Indonesia adalah bakso. Selain itu, makanan juga bisa menjadi sebuah sub kultural golongan tertentu yang menggambarkan sesuatu serta mengidentifikasi suatu golongan. Makanan-makanan ini meliputi daging babi untuk masyarakat Kristen, ketupat bagi orang-orang Muslim pada saat hari raya Lebaran, masyarakat Tionghoa pada saat hari raya Imlek.

Makanan adalah suatu unsur budaya yang mencirikan budaya komunitas tertentu. Hal ini dapat kita ketika seseorang berbicara mengenai gudeg, mayoritas orang akan berpikiran mengenai kota Yogyakarta sebagai wilayah di mana gudeg menjadi makanan khas wilayah tersebut. Di dalam sebuah makanan, masyarakat tidak hanya 
memakan makanan secara material, tetapi juga mengkonsumsi keagungan serta kreativitas budaya yang terdapat dalam suatu makanan. Tidak heran jika seseorang membeli sesuatu makanan akan terasa hampa jika membelinya di luar daerah makanan khas daerah tersebut.

Makanan dapat dijadikan ikon keunggulan serta ciri khas suatu daerah. Semakin beraneka ragam makanan ini diketahui publik semakin banyak apresiasi tertuju kepada makanan suatu daerah. Hal ini juga menyebabkan meluasnya jangkauan distribusi makanan itu yang dapat menunjukkan kualitas makanan tersebut telah diketahui oleh masyarakat luas.

Secara tradisional, makanan dapat diproduksi melalui sektor pertanian. Dengan perkembangnya perhatian mengenai agribisnis atas perusahaan-perusahaan multinasional yang mempunyai pasokan makanan dengan melakukan modifikasi secara genetis pada makanan, telah menjadi sebuah tren yang berkembang dalam praktik pertanian.

Produksi makanan secara modern ini juga dapat membawa perubahan secara sosialbudaya. Hal ini bisa terjadi jika dilihat secara detail. Jika produksi makanan dilakukan secara tradisional, maka akan muncul kerja sama dan saling gotong royong antar masyarakat yang membuat meningkatnya rasa solidaritas antar masyarakat. Sebaliknya, jika produksi makanan menggunakan cara modern memakai teknologi yang canggih, hal ini dapat meregangkan hubungan antar masyarakat karena sedikitnya tenaga kerja yang dibutuhkan.

Pola makan masyarakat memiliki perbedaan di setiap daerah. Kepercayaan masyarakat terhadap suatu makanan tertentu dapat menjadi faktor dalam memilih pola konsumsi kalangan tertentu. Pada golongan anak-anak dan remaja, pola makan dipengaruhi oleh 
budaya masyarakat di tempat mereka tinggal. Biasanya budaya ini memiliki suatu aturan bahwa makanan tertentu pantang untuk dimakan atau tabu untuk dimakan.

Tetapi, dengan adanya globalisasi membuat pola makan anak-anak serta remaja berubah ke makanan instan, makanan ringan, serta makanan yang mengandung gula yang berlebih. Makanan-makanan seperti akan merusak kesehatan orang-orang yang mengkonsumsinya.

Di masa modern saat ini, perkembangnya industrialisasi serta pengolahan bahan makanan membuat makanan ini dapat dijangkau serta disebarkan ke lokasi yang jauh. Dengan adanya idustrialisasi ini juga melahirkan supermarket. Supermarket menawarkan pendekatan self service serta menjual makanan yang memiliki kualitas tinggi dengan harga yang rendah. Supermarket menggunakan daya beli untuk menyediakan bahan makanan dari petani. Tetapi, petani menerima sedikit dari keuntungan yang diperoleh oleh suatu supermarket tertentu.

2. Masalah budaya terhadap gizi

Masalah gizi kini sangat luas, gizi di sini tidak hanya berhubungan dengan masalah pangan,kesehatan, dan pengasuhan tetapi masalah gizi di sini juga berhubungan dengan masalah sosial ekonomi,budaya,pendidikan dan lingkungan, dalam tulisan ini sedikit saya membahas masalah pengaruh budaya terhadap status gizi masyarakat. Kita pasti tahu bahwa saat ini kemiskinan adalah penyebab utama masalah gizi kurang di indonesia. Faktor budaya sebenarnya masalah yang menyebabkan terjadinya kemiskinan yang tentunya berdampak pada masalah gizi. Kita lihat saja mulai dari perilaku masyarakat kota dan desa di sertai dengan budaya-budaya mereka sangatsangat berbeda kebutuhan pangan dan status sosial mereka. Dari perbedaan ini kita bisa membandingkan bahwa masyarakat kota tingkat pengetahuan mereka akan masalah 
gizi dan pola-pola hidup yang mereka jalani lebih cenderung pada kemajuan teknologi,ekonomi,pengetahuan status gizi mulai dari menu seimbang untuk pola konsumsi mereka.sedangkan masyarakat pedesaan lebih dekat pada masalah kemiskinan,artinya banyak kekurangan mulai dari kurangnya pengetahuan akan maslah gizi, kurangnya ketersediaan pangan,sampai kirangnya kualitas lingkungan yang baik.

Tanah air kita ini memiliki bermacam-macam budaya di dalamnya dari sabang sampai merauke, dengan suku dan tata kehidupan sosial yang berbeda pula,hal ini telah memberikan struktur sosial yang memenuhi menu makan maupun pola makanya, kecenderungan muncul dari suatu budaya terhadap makanan sangat bergantung pada potensi alamnya atau faktor pertanian yang dominan. Sesungguhnya kebudayaan itu terjadi karena adnya perilaku atau kebiasaan masyarakat dalam suatu tempat,kemudian kebiasaan ini berkembang dari zaman ke zaman yang akan menurun pada keturunan mereka kadang masyarakat itu menganggap ada kekuatan lebih besar selain dari manusia,yakni tuhan.

Pengaruh budaya terhadap gizi ada pengaruh yang negatif dan ada pengaruh yang positif, dampak negatifnya munculnya masalah kekurangan gizi di masyarakat sekitar karena masyarakat sulit meninggalkan kebiasaan-kebiasaan mereka, mereka lebih percaya pada hal-hal yang di anggap tabuh dalam budaya mereka sehingga apa yang sebenarnya tubuh butuhkan tidak terpenuhi sehingga banyak menimbulkan penyakit

Alangkah baiknya kita masyarakat bersama-sama menanggapinya dan mencegahnya dengan memperhatikan sumber daya yang kita miliki memilih makanan yang baik,hingga merubah kebiasaan-kebiasaan yang bermasalah yang dapat mempengaruhi asupan-asupan kebutuhan tubuh kita. 
Stunting adalah kondisi gagal pertumbuhan pada anak akibat kekurangan gizi dalam waktu yang lama. Menurut WHO, Indonesia termasuk ke dalam negaralketiga dengan prevalensi tertinggi di regional Asia Tenggara/South-East Asia Regional (SEAR). Rataratalprevalensi balita stunting di Indonesia tahun 2005-2017 adalah 36, 4\%, sehingga persentase balita pendek di Indonesia masih tinggi. Menurut Riskesdas tahun 2018, provensi sualawesi selatan masih berada di angka 35, 4\%, dengan kabupaten Enrekang tertiggi ke-5 dengan persentase 42\%. Data PSG tahun 2018 menunjukkan bahwa kecamatan yang memiliki prevalensi stunting tertinggi yaitu Kecamatan Baraka sebesar $45,1 \%$. Tujuan penelitian untuk mengetahui bagaimana hubungan sosial budaya dengan kejadian stunting pada baita usia 24-59 bulan di Desa Bone-Bone Kecamatan Baraka Kabupaten Enrekang tahun 2020. Penelitian ini menggunakan metode kuantitatif dengan pendekatan cross sectional. Data dikumpulkan melalui wawancara menggunakan kuesioner dengan teknik total sampling. Jumlah populasi dalam penelitin ini adalah 34 balita, dan jumlah sampel juga sebanyak 34 balita karena menggunakan total sampling. Hasil penelitian menunjukkan bahwa terdapat hubungan antara dukungan keluarga $(p=0,050)$ dengan kejadian stunting tidak terdapat hubungan antara sosial budaya $(\mathrm{p}=0,0281)$, kepercayaan makanan $(\mathrm{p}=0,089)$, dan pengasuhan anak $(\mathrm{p}=$ 1.000) dengan kejadian stunting pada balita usia 24-59 bulan.

3. Mengatasi masalah budaya dan makanan terhadap gizi dan makanan

Masalah budaya dan makanan kita ketahui dapat menyebabkan masalah gizi yang berdampak pada kesehatan tubuh manusia, sehingga perlu secara cermat untuk memberdayakan masyarakat lokal dengan kearifan dan kecerdasan lokal (local wisdom and local genius) disamping terus melaksanakan penyuluhan gizi sebagai alternative mengatasi masalah budaya dan makanan. Pendekatan yang paling utama adalah melalui perbaikan struktur sosial masyarakat tentang pandangan mereka terhadap bahan makanan walaupun lokal tetapi kaya akan nilai gizi. 
Langkah-langkah yang ditempuh seperti:

- Perbaikan gizi keluarga dengan melakukan lomba menyiapkan hidangan makanan non beras (kasus budaya Timor),

- Perbaikan budaya masyarakat dengan pengaruh utama gender terutama di tingkat keluarga.

- Memperluas areal pertanian dengan menanam berbagai komoditi yang mempunyai nilai gizi tinggi sebagai bahan pangan/makanan seperti kedelai (kasus budaya Jawa).

- Pemberian makanan tambahan yang bernilai gizi bagi anak-anak balita dan orang lanjut usia.

- Penyuluhan gizi terpadu dan konsultasi gizi bagi masyarakat.

- Melakukan pengkajian/penelitian dan riset untuk melihat pengaruh budaya terhadap makanan itu sendiri dengan berbagai implikasi yang terkait didalamnya. 


\section{DAFTAR PUSTAKA}

Muhammad Dicky Saifudin .July 27,2020 "Pengaruh budaya terhadap pola makan masyarakat di Indonesia" https://www.rancah.com/kuliner/91112/pengaruh-budayaterhadap-pola-makan-masyarakat-indonesia/ , diakses pada tanggal 8 Desember 2021 pukul 23.10 WITA.

November 11,2014 "Pengaruh atau masalah budaya terhadap gizi" https://www.kompasiana.com/algitaagnestia/54f93e7da333116f068b493f/pengaruhbudaya-terhadap-status-gizi-masyarakat, diakses pada tanggal 8 Desember 2021 pukul 23.34 WITA.

Irviani Anwar Ibrahim, Syamsul Alam, Andi Syamsiah Adha, Yusma Indah Jayadi, Muhammad Fadlan, 2021 "Hubungan Sosial Budaya Dengan Kejadian Stunting Pada Balita Usia 24-59 Bulan Di Desa Bone-Bone Kacamatan Baraka Kabupaten Enrekang Tahun 2020",

https://scholar.google.com/citations?view op=view citation\&hl=id\&user $=5 \mathrm{xW} 4 \mathrm{cx} 4 \mathrm{AA}$ AAJ\&citation_for_view $=5 \mathrm{xW} 4 \mathrm{cx} 4 \mathrm{AAAAJ}: \mathrm{kNdYIx}-\mathrm{mwKoC}$, di akses pada tanggal 9 Desember 2021 pukul 00.02 WITA.

La Banudi dan Imanuddin, 2017.Buku Sosiologi dan Antropologi Gizi“Mengatasi Masalah Budaya dan makanan terhadap gizi" http://repository.poltekkeskdi.ac.id/1371/1/BUKU\%20SOSIOLOGI\%20DAN\%20ANTROPOLOGI\%20GIZI.pdf Di akses pada tanggal 9 Desember 2021, pukul 00.18 WITA. 